\title{
Nurses, nursing technicians and assistants: who experiences more moral distress?*
}

\author{
ENFERMEIROS, TÉCNICOS E AUXILIARES DE ENFERMAGEM: QUEM VIVENCIA \\ MAIOR SOFRIMENTO MORAL?
}

\section{ENFERMEROS, TÉCNICOS Y AUXILIARES DE ENFERMERÍA: ¿QUIÉN EXPERIMENTA EL MAYOR SUFRIMIENTO MORAL?}

\author{
Graziele de Lima Dalmolin ${ }^{1}$, Valéria Lerch Lunardi ${ }^{2}$, Guilherme Lerch Lunardi ${ }^{3}$ Edison Luiz \\ Devos Barlem ${ }^{4}$, Rosemary Silva da Silveira ${ }^{5}$
}

\begin{abstract}
Objective: To identify the frequency and intensity of moral distress experienced by nurses, technicians and nursing assistants who worked in hospitals in the South of Rio Grande do Sul State. Method: A survey research was conducted with 334 nursing workers from three institutions, through a questionnaire of moral distress. Constructs were validated through factorial analysis and Cronbach's alpha: lack of competence of the working team, disrespect to the patient's autonomy, insufficient working conditions and therapeutic obstinacy. Results: With descriptive statistics and analysis of variance, it was found that nurses and nursing assistants have higher perception of moral distress when compared to nursing technicians. Organizational questions and ways of communication influence lower perception of moral distress. Conclusion: Implementation of actions to favor coping, decision making and autonomy exercise from those workers.
\end{abstract}

\section{RESUMO}

Objetivo: Identificar a frequência e intensidade de sofrimento moral vivenciadas por enfermeiros, técnicos e auxiliares de enfermagem que atuam em hospitais no Sul do Rio Grande do Sul. Método: Realizou-se uma pesquisa survey com 334 trabalhadores de enfermagem, atuantes em três instituições, por meio da aplicação do questionário de sofrimento moral. Mediante análise fatorial e alfa de Cronbach, validaram-se os constructos: falta de competência na equipe de trabalho, desrespeito à autonomia do paciente, condições de trabalho insuficientes e obstinação terapêutica. Resultados: Com a estatística descritiva e análise de variância, constatou-se que enfermeiros e auxiliares de enfermagem possuem maior percepção de sofrimento moral quando comparados aos técnicos de enfermagem. Questões organizacionais e formas de comunicação influenciam na menor percepção de sofrimento moral. Conclusão: Recomenda-se a implementação de ações que favoreçam enfrentamentos, tomadas de decisão e exercício da autonomia desses trabalhadores.

\section{DESCRITORES}

Ética em enfermagem

Equipe de enfermagem

Autonomia profissional

Esgotamento profissional

Relações interprofissionais

\section{RESUMEN}

Objetivo: Identificar la frecuencia e intensidad del sufrimiento moral experimentado por enfermeros, técnicos y auxiliares de enfermería que trabajan en los hospitales del sur del estado de Rio Grande do Sul. Método: Se realizó una investigación encuesta con 334 trabajadores de enfermería, pertenecientes a tres instituciones, a través de la aplicación del cuestionario de sufrimiento moral. Por medio del análisis factorial y el Alfa de Cronbach, se validaron los constructos: falta de competencia en el equipo de trabajo, falta de respeto a la autonomía del paciente, condiciones de trabajo insuficientes y obstinación terapéutica. Resultados: A través de la estadística descriptiva y el análisis de la varianza, se constató que los enfermeros y auxiliares de enfermería poseen una mayor percepción del sufrimiento moral comparados a los técnicos de enfermería. Los aspectos organizacionales y las formas de comunicación influyen en la menor percepción del sufrimiento moral. Conclusión: Se recomienda la implementación de acciones que favorezcan los enfrentamientos, las tomas de decisiones y el ejercicio de la autonomía de esos trabajadores.

\author{
DESCRIPTORES \\ Ética en enfermería \\ Grupo de enfermería \\ Autonomía profesional \\ Agotamiento profesional \\ Relaciones interprofesionales
}

\footnotetext{
*Extracted from the thesis "Sofrimento moral e síndrome de Burnout: relações nas vivências profissionais de trabalhadores de enfermagem", Nursing Graduate Program, Universidade Federal do Rio Grande, 2012. ${ }^{1}$ Doctor in Nursing. Professor of the Nursing Department, Universidade Federal de Santa Maria, Santa Maria, RS, Brazil. grazi.dalmolin@gmail.com ${ }^{2}$ Doctor in Nursing. Professor of the Nursing Department, Universidade Federal do Rio Grande, Rio Grande, RS, Brazil. ${ }^{3}$ Doctor in Administration. Professor of the Administration Course and of Nursing Graduate Program, Universidade Federal do Rio Grande, Rio Grande, RS, Brazil. ${ }^{4}$ Doctor in Nursing. Professor of the Nursing Graduate Program, Universidade Federal do Rio Grande, Rio Grande, RS, Brazil. ${ }^{5}$ Doctor in Nursing. Professor of the Nursing Graduate Program, Universidade Federal do Rio Grande, Rio Grande, RS, Brazil
} 


\section{INTRODUCTION}

With the recent and continuous scientific and technological advances, many values have been left to a second plan, constituting new challenges daily in the ethics field which can be characterized by conflicts and dilemmas that with its particularities make the exercise of some professions more complex, as nursing ${ }^{(1)}$.

Those conflicts are linked to the occurrence of ethical and moral problems, moral dilemmas and moral distress. Moral problems involve conflict situations between one or more moral values and uncertainty about the correct course of action in the individual, interpersonal, organizational and social levels. Moral dilemmas are perceived in situations where there are two or more possible course of actions and reasons equally imperial, in which the choice of one action can implicate renounce of others. Yet, moral distress happen in situations where professionals know or believe to know the correct action to be taken, but for many reasons, as fear or circumstances that surpass its competence, they cannot follow this course of action to avoid particular harms, and they can have their values and moral agent identities compromised ${ }^{(2)}$.

The occurrence of moral distress is associated with the work organization, involving the insufficient material and human resources, interpersonal relations, lack of institutional support for the autonomy exercise of nurses, disrespect to the patients' rights and death cause by negligence, that is, deaths known as avoidable ${ }^{(3-4)}$.

The development of moral distress in nursing is also associated to aspects related to organizational politics and its impacts on the worker ability to advocate for patients, with the denial of this defense role. Those workers also present an apparent incapacity/difficulty to influence medical decisions regarding the pain and suffering of patients, which also is related to their role to advocate for patients' rights and to the hierarchical structure of power of many hospitals, making it difficult to recognize their knowledge as well as its implementation ${ }^{(5-6)}$.

The occurrence of moral distress present implications to their lives, in the personal dimension, as emotional and physical signals, as well as in the professional dimension, related to the satisfaction at work and career abandonment. These manifestations seems to be strongly related to the difficulty to exercise power in decision making, which make them act many times against their beliefs and values, denying their knowledge $\mathrm{e}^{(7)}$.

In this case, power as strength relations, in the acting spaces of nursing professionals, developed through fights and incessant coping in its contexts, constituting ways of conducts that transform and modify power. The instability characteristic of strength correlations, due to inequality, continually leads to power states, always localized and modifiable; that is, the power is exercised from innumer- ous points and within inequitable and mobile relations, not being able to exist if not in function of a multiplicity of resistance points, present in all network of power ${ }^{(8)}$.

Thus, it is noted that nursing professionals can experience moral distress by difficulties to exercise power, with possibility to have their personal and professional integrity and authenticity compromised. This difficulty is mainly related to common everyday nursing working factors, as decision making referred to the treatment and care of patients, low autonomy, time and resources restrictions and high levels of responsibility ${ }^{(6)}$.

These factors can be associated to the difficulty to resist and realize coping. The resistance as reaction focuses provoking modifications about everyday facts. In this sense, it can be said that the apparent lack of fights from nursing workers can be configured in the non-use of their personal freedom, which can lead them to their own mortification, based on the obedience, resignation and submission ${ }^{(9)}$.

This question can also be related to the disciplinary power, by the apparent subjecting forces, in some dilemma and coping situations, leaving a relationship of docileutility to the nursing workers. The discipline in power relations have the formation of obedient and useful corps, that is, while submissive people are formed, it increases their strength in economic utility level and decrease in political, resistance and fight terms ${ }^{(10)}$.

Considering the diverse aspects linked to the occurrence of moral distress and the possibilities to intensify it inside nursing environments, bringing consequences to workers and compromising the nursing care; the objective of the study was to identify the frequency and intensity of moral distress experienced by nurses, nursing technicians and assistants from hospitals in the South of Rio Grande do Sul State/Brazil.

\section{METHOD}

This is a quantitative approach study, exploratory and descriptive, constituting a survey research.

This survey was conducted with nursing professionals from three hospital institutions $(\mathrm{H} 1, \mathrm{H} 2$ e $\mathrm{H} 3)$ from the South of Rio Grande do Sul State, located in two different municipalities (M1 e M2). In accordance with available data from the Brazilian National Health Facilities from the Informatics Department of SUS (CNES/ DATASUS) and available data from official electronic addresses of the participating institutions, the $\mathrm{H} 1$ institution is characterized as a federal public hospital, with 186 beds and 59 nurses, 52 nursing technicians and 203 nursing assistants. In its majority, they are public employees formally hired, with a weekly schedule of 30 hours. The $\mathrm{H} 2$ institution is characterized as a philanthropic hospital with 658 beds, 76 nurses, 287 nursing
Nurses, nursing technicians and assistants: who experiences more moral distress? Dalmolin GL, Lunardi VL, Lunardi GL, Barlem ELD, Silveira RS 
technicians and 54 nursing assistants, hired and regulated by the Consolidation of Labor Laws (CLT), with a weekly schedule varying from 36 to 40 hours. At last, the $\mathrm{H} 3$ institution is a philanthropic school hospital of public utility, with 291 beds, 60 nurses, 382 nursing technicians and nursing assistants also regulated by the CLT with a 36 hours weekly schedule.

The instrument for data collection was an adaptation from the Moral Distress Scale (MDS) adjusted to the present research context ${ }^{(5)}$. This instrument was originally developed in a North-American context ${ }^{(11)}$, submitted to a back-translation, cultural adaptation and validation process $^{(4)}$, when it was found that in some situations identified in our reality as sources of moral distress, it was not fully contemplated. The questionnaire applied was composed by 39 questions, using a Likert scale of seven points to analyze the intensity and the frequency of moral distress, along with components of subject's characteristics.

As subjects for the present study, we considered nursing professionals from the $\mathrm{H} 1, \mathrm{H} 2$ and $\mathrm{H} 3$, including nurses, technicians and assistants who work in those institutions, which means 1,213 individuals, composing a non-probabilistic convenient sample. A formula was used to select the sample size ${ }^{(12)}$, estimating a minimum of 295 subjects for statistical analysis. The inclusion criteria referred to the availability and interest in responding the instrument at the data collection moment.

The data collection was performed from October 2010 to July 2011. Five hundred questionnaires were given to workers, from those, 387 were returned. We adopted as exclusion criteria for analysis procedures, those questionnaires which the respondents used only two points of the scale, not considering the interval scale adopted; those who marked as not having moral distress in 20 questions or more, and those who left more than 10 items in blank. Thus, with the exclusion of 53 instruments, 334 subjects composed the final sample for data analysis.

After the data collection, two statistical tests were conducted to guarantee the instrument validity: a factorial analysis and the Cronbach's alpha. The factorial analysis aimed to reduce and summarize data, defining groups of latent dimensions, denominated factors ${ }^{(13)}$. From the 39 proposed questions, initially, 20 were validated and pooled in four dimensions - lack of competence of the working team, disrespect to the patient's autonomy, insufficient working conditions and therapeutic obstinacy while 19 were excluded from the instrument because they presented low factorial loads (inferior to 0.40). More elevated factorial loads (superior to 0.40 ) in more than one factor did not present conceptual coherence with the proposed block or formed isolated blocks with only one question. The four proposed dimensions explained $67.68 \%$ of the variation in the original questions, representing an adequate level of data synthesis, facilitating its management and interpretation.
The Cronbach's alpha assess internal consistency between variables of multiple scales ${ }^{(13)}$. Suggested values range between 0.60 and 0.80 for exploratory studies, guaranteeing the reliability of the used scales. The Cronbach's alpha for the instrument presented 0.93 value while the coefficients from the four dimensions were between 0.75 and 0.94 , proving its reliability.

The presented constructs were already identified by other studies about moral distress, firstly with nurses ${ }^{(4)}$ and after with other nursing professionals ${ }^{(5)}$. The referred constructs can be understood in accordance with the following definitions.

Lack of competence of the working team is related to nursing professionals' insecurity about acting with other professionals of the nursing and health teams and, also, with support services, that does not inspire trust. Disrespect to the patient's autonomy refers to the infraction of the autonomy ethic principle, that stipulates individual freedom to each person to determine their actions in accordance with their own choices, values and convictions ${ }^{(1)}$. Insufficient working conditions is related to the work organization, associated with lack of material resources and also, to work overload caused by insufficient human resources ${ }^{(3)}$. Therapeutic obstinacy constitutes the implementation of therapeutic measures recognized by nursing professionals as futile and responsible for the prolonged suffering of terminally ill patients ${ }^{(14)}$.

At last, the data analysis to obtain the results was performed with descriptive statistics and analysis of variance (ANOVA), identifying possible significant differences between respondent groups. The software Statistical Package for Social Sciences (SPSS) version 13.0 was used.

All ethical precepts of research involving human beings were respected, and the project was submitted for evaluation at the local Ethics in Research Committee, with a favorable answer (Protocol no 70/2010).

\section{RESULTS}

In relation to general characteristics of the study participants, we highlight a sample constituted by 334 nursing professionals; from those $71(21.3 \%)$ were nurses, 234 (70\%) were nursing technicians and $29(8.7 \%)$ were nursing assistants; 289 (86.5\%) were female and 39 (11.7\%) were male. Their age varied from 19 to 64 years, the mean value was 33.6 years, and 184 (55\%) subjects had the same or lower age in comparison to the mean and 150 (45\%) subjects had superior age. Regarding the work place, 60 professionals were from $\mathrm{H} 1,183$ from $\mathrm{H} 2$ and 91 from $\mathrm{H} 3$.

Regarding professional qualification, 65.5 and $73.5 \%$ of nursing assistants and technicians respectively, did not look for another course after their education; differently, $63.5 \%$ of nurses were updated with specialized courses $(40.8 \%)$ and master's degree (19.7\%). 
Descriptive analysis allowed the identification of their perception about the moral distress experienced. The four identified constructs were operationalized by numerical values corresponding to arithmetic means from individual questions composing each construct (Table 1).

Table 1 - Means of intensity and frequency of moral distress experienced by different nursing professionals in accordance with situations represented in questions of a validated instrument - Rio Grande, RS, 2012

\begin{tabular}{|c|c|c|c|c|c|}
\hline \multirow{3}{*}{ Variables } & \multicolumn{5}{|c|}{ Means } \\
\hline & \multicolumn{4}{|c|}{ Intensity } & \multirow{2}{*}{$\begin{array}{l}\text { Freq } \\
\text { Geral }\end{array}$} \\
\hline & Assist & Tech & Nurse & Geral & \\
\hline Lack of competence of the working team & & & & 4.05 & 2.47 \\
\hline $\begin{array}{l}\text { q25 - To work with nursing technician/assistants lacking the necessary competence for } \\
\text { the needed condition of the patient. }\end{array}$ & 4.1 & 3.93 & 4.46 & 4.06 & 2.43 \\
\hline $\begin{array}{l}\text { q26 - To work with Medical or Nursing students lacking the necessary competence for } \\
\text { the needed condition of the patient. }\end{array}$ & 4.38 & 3.89 & 4.37 & 4.04 & 2.53 \\
\hline $\begin{array}{l}\text { q27 - To work with physicians lacking the necessary competence for the needed condi- } \\
\text { tion of the patient. }\end{array}$ & 4.66 & 3.92 & 4.69 & 4.15 & 2.6 \\
\hline $\begin{array}{l}\text { q28 - To work with support services physicians lacking the necessary competence for } \\
\text { the needed condition of the patient. }\end{array}$ & 4.07 & 3.8 & 4.28 & 3.93 & 2.61 \\
\hline q29 - To work with nurses lacking competence to act. & 4.17 & 3.93 & 4.27 & 4.02 & 2.25 \\
\hline q31 - To work with physicians lacking competence to act. & 3.93 & 4.05 & 4.69 & 4.17 & 2.45 \\
\hline q32 -To work with support services lacking competence to act. & 3.89 & 3.82 & 4.37 & 3.95 & 2.37 \\
\hline q33 -To work with Medical and Nursing students lacking competence to act. & 4.07 & 4.02 & 4.53 & 4.13 & 2.5 \\
\hline Disrespect to the patient's autonomy & & & & 3.47 & 1.81 \\
\hline $\begin{array}{l}\text { q17 - To follow the medical order of not telling the truth to the patient, even when the } \\
\text { patient asks you the truth. }\end{array}$ & 4.31 & 3.79 & 4.31 & 3.95 & 2.14 \\
\hline $\begin{array}{l}\text { q21 - To consider the medical request of not arguing with the patient about his reani- } \\
\text { mation in case of heart failure. }\end{array}$ & 3.52 & 3.18 & 3.76 & 3.34 & 1.71 \\
\hline $\begin{array}{l}\text { q22 - To consider the medical request of not arguing with the family about the pa- } \\
\text { tient's reanimation in case of heart failure, when the patient is lacking discernment. }\end{array}$ & 3 & 3.19 & 3.87 & 3.32 & 1.69 \\
\hline $\begin{array}{l}\text { q23 - To consider the medical request about not talking about death with a dying } \\
\text { patient when he asks you about death. }\end{array}$ & 3.41 & 3.11 & 3.85 & 3.29 & 1.7 \\
\hline Insufficient working conditions & & & & 3.65 & 2.45 \\
\hline q01 - To improvise when facing the lack of material in the patient's care. & 3.69 & 3.41 & 2.96 & 3.34 & 2.95 \\
\hline $\mathrm{q} 06$ - Not possess the needed materials to care for the patient. & 3.66 & 3.58 & 3.72 & 3.61 & 2.48 \\
\hline q08 - Not possess the needed equipment for a patient urgency care. & 4.41 & 3.7 & 4.45 & 3.92 & 2.26 \\
\hline $\begin{array}{l}\text { q14- The need to prioritize the patients to be cared of due to insufficient human } \\
\text { resources. }\end{array}$ & 3.9 & 3.81 & 4.45 & 3.95 & 2.32 \\
\hline $\begin{array}{l}\text { q15 - The need to delegate nursing care to the patient's family due to insufficient hu- } \\
\text { man resources. }\end{array}$ & 3.45 & 3.32 & 3.86 & 3.44 & 2.25 \\
\hline Therapeutic Obstinacy & & & & 3.6 & 2.31 \\
\hline $\begin{array}{l}\text { q05 - To start intensive procedures to save a life, when you believe they will only } \\
\text { postpone death. }\end{array}$ & 4.07 & 3.65 & 3.44 & 3.65 & 2.57 \\
\hline $\begin{array}{l}\mathrm{q} 11 \text { - To assist doctors who are doing procedures in patients after a non-satisfactory } \\
\text { cardiorespiratory recovery. }\end{array}$ & 4.34 & 3.57 & 3.54 & 3.63 & 2.08 \\
\hline $\begin{array}{l}\mathrm{q} 12 \text { - To execute medical prescriptions for the procedure of exams and treatments in } \\
\text { terminally ill patients. }\end{array}$ & 3.93 & 3.4 & 3.77 & 3.53 & 2.29 \\
\hline
\end{tabular}

When analyzing individual means of the composing questions of each one of the four constructs, we observed that the following questions presented the higher means: in the construct lack of competence of the working team, the question q31 - To work with physicians lacking competence to act (4.17); in disrespect to the patient's autonomy, the question q17- to follow the medical order of not telling the truth to the patient, even when the patient asks you the truth (3.95); in insufficient working conditions, the question $q 14$ - the need to prioritize the patients to be cared of due to insufficient human resources (3.95); and, in therapeutic obstinacy, the question q05 - To start intensive procedures to save a life, when you believe they will only postpone death (3.65).

On the other hand, regarding the frequency in which the nursing professionals experienced moral distress, we observed the means of situations that causes it varying from (1.69) in the question $q 22$ - to consider the medical request of not arguing with the family about the patient's reanimation in case of heart failure, when the patient is lacking discernment, as the least frequent, un- 
til (2.95) in the question q01 - To improvise when facing the lack of material in the patient's care, as the most frequent. We also noted that in relation to the constructs, the higher frequency mean was in lack of competence in the working team (2.47), followed by insufficient working conditions (2.45).
Through descriptive analysis, it was possible to verify total means of each construct in accordance with different categories of nursing professionals. We also conducted an analysis of the total moral distress, in accordance with the three professionals' categories, considering the constructs formed in the factorial analysis (Table 2).

Table 2 - Total mean of moral distress experienced by nursing assistants, technicians and nurses in accordance with four proposed constructs in the factorial analysis - Rio Grande, RS, 2012

\begin{tabular}{|c|c|c|c|c|c|}
\hline \multirow[b]{2}{*}{ Variables } & \multirow{2}{*}{$\begin{array}{l}\text { Total } \\
\mathbf{n}=\mathbf{3 3 4}\end{array}$} & \multicolumn{3}{|c|}{ Category } & \multirow[b]{2}{*}{$\mathbf{P}$} \\
\hline & & $\begin{array}{c}\text { Assistant } \\
\mathbf{n}=\mathbf{2 9}\end{array}$ & $\begin{array}{c}\text { Technician } \\
\mathrm{n}=234\end{array}$ & $\begin{array}{c}\text { Nurse } \\
\mathrm{n}=71\end{array}$ & \\
\hline Lack of competence of the working team & 4.05 & 4.16 & 3.92 & 4.45 & 0.02 \\
\hline Disrespect to the patient's autonomy & 3.47 & 3.56 & 3.31 & 3.93 & 0.02 \\
\hline Insufficient working conditions & 3.65 & 3.82 & 3.56 & 3.89 & 0.16 \\
\hline Therapeutic obstinacy & 3.6 & 4.11 & 3.54 & 3.58 & 0.17 \\
\hline Total moral distress & 3.69 & 3.91 & 3.58 & 3.96 & 0.04 \\
\hline
\end{tabular}

Regarding the four analyzed constructs, two presented significant statistical difference (at a $5 \%$ level): lack of competence of the working team $(P=0.02)$ and disrespect to the patient's autonomy $(P=0.02)$. From this data, we perceived that nurses presented higher means of moral distress in lack of competence of the working team (4.45) and disrespect to the patient's autonomy (3.93). We also noted more elevated means for the nursing assistants in all constructs in comparison with the means presented by the nursing technicians.

For the constructs insufficient working conditions and therapeutic obstinacy, it was not possible to find significant statistical difference (at a $5 \%$ level) between the analyzed groups. However, nurses also presented higher means in insufficient working conditions (3.89), but in therapeutic obstinacy they presented a 3.58 mean, while the nursing assistants, 4.11. This difference can be associated to the nursing assistance everyday presence with the patient to perform direct care, seeing their pain and suffering closer in situations without possible cure.

Regarding the analysis of total moral distress, we also found significant statistical difference $(P=0.04)$, making it possible to affirm that nurses and nursing assistants have a higher perception of experienced moral distress than nursing technicians.

Still, aiming to analyze the existence of possible mean differences for the four constructs in relation to moral distress, different variance analysis (ANOVA) were conducted, considering subject's particularities, as presented in Table 3.

Table 3 - Relationship between the perception of moral distress in nursing professionals in accordance with identified constructs, characteristics of subjects and work - Rio Grande, RS, 2012

\begin{tabular}{|c|c|c|c|c|c|c|c|c|c|c|c|}
\hline \multirow[b]{2}{*}{ Variables } & \multicolumn{3}{|c|}{$\begin{array}{c}\text { Lack of competence of the } \\
\text { working team }\end{array}$} & \multicolumn{2}{|c|}{$\begin{array}{l}\text { Disrespect to the } \\
\text { patient's autonomy }\end{array}$} & \multicolumn{2}{|c|}{$\begin{array}{l}\text { Insufficient working } \\
\text { conditions }\end{array}$} & \multicolumn{2}{|c|}{$\begin{array}{c}\text { Therapeutic } \\
\text { obstinacy }\end{array}$} & \multicolumn{2}{|c|}{ Total moral distress } \\
\hline & $\mathrm{N}$ & $\mathrm{M}$ & $\mathrm{P}$ & $\mathrm{M}$ & $\mathrm{P}$ & $\mathrm{M}$ & $\mathrm{P}$ & $\mathrm{M}$ & $\mathrm{P}$ & $\mathrm{M}$ & $\mathrm{P}$ \\
\hline \multicolumn{12}{|l|}{ Institution } \\
\hline H1 & 60 & 4.85 & $0.000 *$ & 3.88 & $0.000^{*}$ & 4.37 & $0.000^{*}$ & 4.02 & $0.000 *$ & 4.28 & $0.000^{*}$ \\
\hline $\mathrm{H} 2$ & 183 & 3.96 & & 3.71 & & 3.69 & & 3.74 & & 3.78 & \\
\hline $\mathrm{H} 3$ & 91 & 3.71 & & 2.72 & & 3.1 & & 3.02 & & 3.14 & \\
\hline \multicolumn{12}{|c|}{ Time to finish education } \\
\hline$\geq 5$ years & 108 & 4.31 & $0.018^{*}$ & 3.52 & 0.534 & 3.95 & $0.002 *$ & 3.77 & 0.118 & 3.89 & $0.025^{*}$ \\
\hline$<5$ years & 211 & 3.92 & & 3.4 & & 3.48 & & 3.47 & & 3.57 & \\
\hline \multicolumn{12}{|c|}{ Permanent education } \\
\hline Yes & 181 & 3.96 & 0.063 & 3.44 & 0.096 & 3.59 & 0.372 & 3.61 & 0.065 & 3.65 & $0.049^{*}$ \\
\hline No & 54 & 4.46 & & 3.87 & & 3.88 & & 3.96 & & 4.04 & \\
\hline I don't know & 97 & 3.98 & & 3.27 & & 3.64 & & 3.34 & & 3.56 & \\
\hline \multicolumn{12}{|l|}{ Meetings } \\
\hline Yes & 146 & 4.06 & 0.978 & 3.42 & 0.608 & 3.52 & 0.106 & 3.39 & $0.032 *$ & 3.6 & 0.192 \\
\hline \multirow[t]{2}{*}{ No } & 187 & 4.05 & & 3.51 & & 3.76 & & 3.77 & & 3.77 & \\
\hline & & & & & & & & & & & Continued. \\
\hline $\begin{array}{l}\text { Nurses, nursing te } \\
\text { who experiences } \\
\text { Dalmolin GL, Lunardi } \\
\text { Silveira RS }\end{array}$ & $\begin{array}{l}\text { icians } \\
\text { moral } \\
\text { unardi }\end{array}$ & $\begin{array}{l}\text { stants } \\
\text { ? } \\
\text { ELD, }\end{array}$ & & & & & & & $\begin{array}{l}\text { Esc Enf } \\
\text { 2014; } 48 \\
\text { ee.usp.b }\end{array}$ & $\begin{array}{l}\text { erm USP } \\
\text { ):519-26 } \\
\text { /reeusp/ }\end{array}$ & $5 ?$ \\
\hline
\end{tabular}




\begin{tabular}{|c|c|c|c|c|c|c|c|c|c|c|c|}
\hline \multirow[b]{2}{*}{ Variables } & \multicolumn{3}{|c|}{$\begin{array}{c}\text { Lack of competence of the } \\
\text { working team }\end{array}$} & \multicolumn{2}{|c|}{$\begin{array}{l}\text { Disrespect to the } \\
\text { patient's autonomy }\end{array}$} & \multicolumn{2}{|c|}{$\begin{array}{l}\text { Insufficient working } \\
\text { conditions }\end{array}$} & \multicolumn{2}{|c|}{$\begin{array}{l}\text { Therapeutic } \\
\text { obstinacy }\end{array}$} & \multicolumn{2}{|c|}{ Total moral distres } \\
\hline & $\mathrm{N}$ & M & $\mathrm{P}$ & M & $\mathrm{P}$ & M & $\mathrm{P}$ & M & $\mathrm{P}$ & M & $\mathrm{P}$ \\
\hline \multicolumn{12}{|c|}{ Institution dialogue } \\
\hline Yes & 122 & 3.96 & 0.157 & 3.39 & 0.6 & 3.35 & $0.007 *$ & 3.41 & 0.221 & 3.53 & 0.161 \\
\hline No & 72 & 3.87 & & 3.63 & & 3.86 & & 3.77 & & 3.78 & \\
\hline Sometimes & 140 & 4.23 & & 3.46 & & 3.81 & & 3.67 & & 3.79 & \\
\hline \multicolumn{12}{|c|}{ Management dialogue } \\
\hline Yes & 192 & 4.04 & 0.975 & 3.48 & 0.382 & 3.5 & $0.047^{*}$ & 3.48 & 0.111 & 3.63 & 0.266 \\
\hline No & 42 & 4.08 & & 3.75 & & 3.97 & & 4.03 & & 3.96 & \\
\hline Sometimes & 100 & 4.07 & & 3.33 & & 3.81 & & 3.64 & & 3.71 & \\
\hline
\end{tabular}

Note: $\left(^{*}\right)$ Statistical difference at a $5 \%$ level.

In the relationship between the constructs, the personal and labor characteristics from nursing professionals, we identified few items with a significant statistical difference at a $5 \%$ level that influences the perception of moral distress. Within them, the institution where they work, that is, workers from $\mathrm{H} 1$ presented higher perception of moral distress, with a 4.28 mean of total moral distress, followed by workers from $\mathrm{H} 2$ with a 3.78 mean and $\mathrm{H} 3$, with 3.14.

Regarding the time to conclude their education in Nursing, we noted that workers with more time after graduation, that is, more than five years, presented higher perception of experience of moral distress in the constructs lack of competence of the working team (4.31), insufficient working conditions (3.95) and the analysis of total moral distress (3.89).

About actions towards permanent education in the institution, workers that affirmed to not have this type of activity in their workplace presented higher perception in of total moral distress (4.04).

The workers who affirmed to not have meetings within the working team presented higher perception of moral distress associated to therapeutic obstinacy (3.77). Lastly, we found nursing workers who perceived as not having dialogue with the institution and managers presenting higher moral distress related to insufficient working conditions, with means of (3.86) and (3.97), respectively.

\section{DISCUSSION}

From the data analysis, four constructs were defined and those are related to experiences of moral distress from nursing professionals, within them: lack of competence of the working team (4.05); disrespect to the patient's autonomy (3.47); insufficient working conditions (3.65); and therapeutic obstinacy (3.60). Lastly, a total moral distress analysis calculated from the four defined constructs means presented a 3.69 value.

Identified constructs in this case were also established in other studies about perception of moral distress in nursing. In a sample of 124 nurses in the South of Rio
Grande do Sul, the following dimensions were identified: lack of competence of the working team, therapeutic obstinacy, disrespect to the patient's autonomy, with 4.55, 3.60 and 3.57 means respectively ${ }^{(4)}$. In another sample of 247 nursing professionals, including different nursing professional categories, they also identified the dimensions lack of competence of the working team, disrespect to the patient's autonomy and insufficient working conditions; again, the first with the highest mean, that is, $4.36^{(5)}$. Thus, in those samples, other different constructs were seen, within them: denial of the nurse/nursing role as advocate of the patient ${ }^{(4-5)}$ and denial of the nursing as advocate of the terminally ill patient ${ }^{(5)}$.

Considering the questions presenting higher means in each construct, as shown in Table 1, we perceive the experience of moral suffering in the four constructs identified in this research to be articulated with the difficulty of nursing professionals to exercise power, to cope and facing who represents power in the working environment micro spaces, that is, difficulty to establish points of resistance in power relations, which can, as referred, compromise their moral integrity ${ }^{(15)}$.

This question can be influenced by disciplinary formation, which increases in strength of the body in economical and utility terms, but diminishes in political terms by obedience and passivity ${ }^{(10)}$, inducing to its own mortification by the production of individuals with diminished capacities to revolt, resist and fight, making them become politically docile(15), besides more involved questions. This way, it is necessary for multiple relations of power in the working environment to consider it in a manner to favor personal freedom and a moral posture in agreement with the practice to be performed ${ }^{(15)}$.

Considering all other presented results, we infer that nurses presents higher perception of total moral distress that can be associated in its different education/ formation, regarding the number of hours spent during undergraduate nursing education. Comparing to other categories of nursing, they seem to receive more emphasis during its construction as workers who privilege a holistic humanitarian model, contextualized in caring, with 
development of critical, reflexive, creative and ethical abilities for professional practice ${ }^{(16)}$, which possibly contribute to identify moral problems; in contradiction, but seems to present difficulties to perform confronting that they can recognize as needed to assure coherent actions with their moral values. Thus, the major moral distress between nurses can also be associated to their conscience of not corresponding to what could be their roles in front of the other nursing workers, as they have a coordinating posture in the nursing team, what implicates a leadership role and a possible model/reference to their team.

Regarding the time after their education conclusion in the nursing field, the graduated workers of five years or more presented higher perception of total moral distress, and related to lack of competence of the working team and insufficient working conditions. More time after conclusion of the course associated with a higher perception of moral distress experience can be related to more maturity and professional experience that allows to problematize and analyze more critically the experiences in the working context, identifying the most correct actions, but without being able to implement those, possibly due to the difficulties regarding the confrontations that would be needed, which intensifies their perception of compromise of their moral agency.

Regarding the activities of permanent education, those can be considered as an essential strategy to form and develop health professionals, acting in the perspective to qualify the offered services ${ }^{(17)}$. This way, professionals aware of permanent education actions in their institutions and, probably participating in those, present lower perception of moral distress due to the higher probability of reflection, sharing and discussing conflicting questions and dilemmas with their work colleagues.

Some ways of communication experienced in working environments were also assessed, as meetings within the team and the perception of dialogue with the institution, managers and team. It was found that workers who report to not attend to meetings, experience higher moral distress related to therapeutic obstinacy, as well as those who do not have the possibility of dialogue with managers and institutions that also experience higher moral distress related to insufficient working conditions.

Thus, to maintain an adequate and capable environment for a nursing care with quality, it is needed the existence of relationships and spaces that allow the problematization and the manifestation of experienced difficulties, preferably a permanent dialogue with managers and administrations, especially those referred to human resources and needed materials.

Considering those results, in a sense of diminish the moral distress experienced by nursing professionals, identified strategies in the literature can be cited, regarding ethical education through formation and strengthening of ethic commissions and permanent education programs; improvements in communication, and improvement in organizational questions, with more participation of nursing professionals in the creation of institutional policies, as in a better distribution of human resources and materials ${ }^{(18-19)}$.

In relation to communication strategies, those appear as an option to decrease moral distress, the opportunities that nursing professionals have to consult their colleagues and debate about situations that cause anguish. In a daily practice, the moral questions are not sufficiently contemplated and discussed many times, but it is emphasized that workers and institutions should find ways to create this moral debate, in favor of their professional self-esteem ${ }^{(20)}$. Other sources of support and coping moral distress, besides the work in team and sharing anguish with their peers, it is related to the institutional management strengthening, which can favor dialogue, autonomy and decision making, establishing an ethic committee to defend the quality of care and workers, and class organizations assisting the prevention of moral distress through the advocacy for better work conditions, respect to the worker's rights and opportunities for professional growth ${ }^{(21)}$.

At last, with these strategies, the favor of the nursing worker's conduct can exist as the defenders of the patients' rights ${ }^{(22)}$, because prepared and strong, they can promote discussions and possibilities to cope with conflict situations in the daily practice of nursing, contributing, consequently, for the decrease of moral distress ${ }^{(18-19,21)}$.

\section{CONCLUSION}

This study aimed to explore the perception of moral distress experienced by nursing professionals in different institutions. Firstly, we identified as source of moral distress, the following formed constructs: lack of competence of the working team, disrespect to the patient's autonomy, insufficient working conditions and therapeutic obstinacy. In the same way, we tried to look for the relationships of those items with their work environment characteristics.

Resulting from the analysis of means from the questions composing each construct, we considered that constructs and questions with more elevated means for moral distress seem to be related to their difficulties to exercise power and resistance in their working environment, contributing for its mortification and denial of themselves when facing the apparent acceptance of conditions, even inadequate ones, in which they act.

We noticed that within professional categories, nurses are those with higher moral distress, followed by nursing assistants and, after, by the nursing technicians. Regarding the personal and the work environmental characteristics, we found moral distress seem to be more manifested in situations and environments in which meetings are not done within the working team, and there are few possibilities of dialogue with the managers and the institution; in the same way, in places where there is no actions of 
permanent education. Thus, the experience of moral distress, especially, in the working environment organization, which does not propitiate spaces for discussions, problematization, reflection and appreciation of experiences in everyday situations of work that can demand coping from the workers continually.

\section{REFERENCES}

1. Oguisso T, Schmidt MJ. O exercício da enfermagem: uma abordagem ético-legal. 3a ed. Rio de Janeiro: Guanabara Koogan; 2010.

2. Canadian Nurses Association (CNA). Code of ethics for registered nurses. Ottawa, Canada: Centennial; 2008.

3. Dalmolin GL, Lunardi VL, Lunardi Filho WD. O sofrimento moral dos profissionais de enfermagem no exercício da profissão. Rev Enferm UERJ. 2009;17(1):35-40.

4. Barlem ELD, Lunardi VL, Lunardi GL, Dalmolin GL, Tomaschewski JG. The experience of moral distress in nursing: the nurses' perception. Rev Esc Enferm USP [Internet]. 2012 [cited 2013 Feb 22];46(3):681-8. Available from: http://www.scielo.br/pdf/reeusp/v46n3/en_21.pdf

5. Barlem ELD, Lunardi VL, Lunardi GL, Tomaschewski-Barlem JG, Silveira RS. Moral distress in everyday nursing: hidden traces of power and resistance. Rev Latino Am Enferm. 2013;21(1):293-9.

6. Huffman DM, Rittenmeyer L. How professional nurses working in hospital environments experience moral distress: a systematic review. Crit Care Nurs Clin North Am. 2012;24(1):91-100.

7. Dalmolin GL, Lunardi VL, Barlem ELD, Silveira RS. Implicações do sofrimento moral para os(as) enfermeiros(as) e aproximações com o burnout. Texto Contexto Enferm. 2012;21(1):200-8.

8. Foucault M. História da sexualidade I: a vontade de saber. 19ạ ed. Rio de Janeiro: Graal; 1988.

9. Foucault M. História da sexualidade II: o uso dos prazeres. São Paulo: Graal; 1984

10. Foucault M. Vigiar e punir: nascimento da prisão. 36a ed. Petrópolis: Vozes; 2009.

11. Corley MC, Elswick RK, Gorman M, Clor T. Development and evaluation of moral distress scale. J Adv Nurs. 2001;33(2):250-6.

12. Hill MM, Hill A. Investigação por questionário. Lisboa: Sílado; 2002.
Thus, we recommend the implementation of actions to enhance working conditions and communication in environments with nursing action, prioritizing coping, decision making, the autonomy exercise and especially, the quality of nursing care and the process of health/satisfaction of their professionals.

13. Hair JF, Anderson RE, Tatham RL, Black WC. Análise multivariada de dados. Porto Alegre: Artmed; 2005.

14. Carvalho KK, Lunardi VL. Obstinação terapêutica como questão ética: enfermeiras de unidade de terapia intensiva. Rev Latino Am Enferm [Internet]. 2009 [citado 2013 fev. 15];17(3). Disponível em: http://www.scielo.br/pdf/rlae/ v17n3/pt_05.pdf

15. Foucault M. Microfísica do poder. 26a ed. Rio de Janeiro: Graal; 2008.

16. Brasil. Conselho Nacional de Educação. Câmara de Educação Superior. Resolução CNE/CES n. 3, de 7 de novembro de 2001. Institui Diretrizes Curriculares Nacionais do curso de graduação em enfermagem [Internet]. Brasília; 2001 [citado 2012 nov. 20]. Disponível em: http://portal.mec.gov.br/cne/ arquivos/pdf/CESO3.pdf

17. Duarte MLC, Oliveira Al. Compreensão dos coordenadores de serviços de saúde sobre educação permanente. Cogitare Enferm. 2012;17(3):506-12.

18. Pijl-Zieber E, Hagen B, Armstrong-Esther C, Hall B, Akins L, Stingl M. Moral distress: an emerging problem for nurses in long-term care? Qual Ageing. 2008;9(2):39-48.

19. Rice EM, Rady MY, Hamrick A, Verheijde JL, Pendergast DK. Determinants of moral distress in medical and surgical nurses an adult acute tertiary care hospital. J Nurs Manag. 2008;16(3):360-73.

20. Veer AJE, Francke AL, Struijs A, Willems DL. Determinants of moral distress in daily nursing practice: a cross sectional correlational questionnaire survey. Int J Nurs Stud. 2013;50(1):100-8.

21. Maluwa VM, Andre J, Ndebele P, Chilemba E. Moral distress in nursing practice in Malawi. Nurs Ethics. 2012;19(2):196-207.

22. Lang KR. The Professional ills of moral distress and nurse retention: is ethics education an antidote? Am J Bioeth. 2008;8(4):19-21.

\section{Support}

Financial support from the Brazilian National Council of Scientific and Technological Development (CNPq), process no 475366/2008-5.

Correspondence addressed to: Graziele de Lima Dalmolin Universidade Federal de Santa Maria, Departamento de Enfermagem Av. Roraima, 1000 - Prédio 26A Sala 1305B - Camobi CEP 97105-900 - Santa Maria, RS, Brasil 